\title{
Regulatory $T$ cells and anti-inflammatory cytokine profile of mice fed a high-fat diet after single-bulb garlic (Allium sativum L.) oil treatment
}

\author{
Sri Rahayu Lestari ${ }^{1 *}$, Muhaimin Rifa'i ${ }^{2}$ \\ ${ }^{1}$ Biology Department, Faculty of Mathematics and Natural Sciences, State University of Malang, ${ }^{2}$ Biology Department, Faculty \\ of Mathematics and Natural Sciences, Brawijaya University, Malang 65145, East Java, Indonesia
}

*For correspondence: Email: srirahayulestari@um.ac.id; Tel: +62 813-3126-4965

\begin{abstract}
Purpose: To analyze the effects of a single-bulb garlic (Allium sativum) oil (SGO) on the activation of regulatory $T$ cells and anti-inflammatory cytokines IL-10 and TGF- $\beta$ in mice fed a high-fat diet (HFD). Methods: The study was conducted with 24 BALB/C male mice divided into six groups consisting of four mice each, i.e., control group (non-HFD, no treatment), HFD group without treatment, HFD administered with simvastatin, and three HFD groups administered SGO doses of 12.5, 25.0 and $50.0 \mathrm{mg} / \mathrm{kg}$, respectively, and continuously treated (with SGO) for 45 days. The relative number of regulatory $T$ cells, IL-10 and TGF- $\beta$ were measured using flow cytometry.

Results: HFD decreased the expression of regulatory $T$ cells, and the production of IL-10 and TGF- $\beta$ compared to the control group $(p<0.05)$. SGO $(50 \mathrm{mg} / \mathrm{kg})$ significantly enhanced the activation of regulatory $T$ cells and production of TGF- $\beta$ in mice fed high-fat diet compared to simvastatin group ( $p<$ $0.05)$. The dose of $25 \mathrm{mg} / \mathrm{kg}$ SGO significantly increased the level of IL-10 in mice fed a HFD $(p<0.05)$. Conclusion: These results suggest that SGO inhibits inflammatory processes in mice fed a HFD, by enhancing regulatory $T$ cells and the anti-inflammatory cytokine IL-10 and TGF- $\beta$. Thus, SGO a promising food supplements and/or therapeutic agent for management of inflammation disorders caused by a HFD.
\end{abstract}

Keywords: Anti-inflammatory agent, Allium sativum, High-fat diet, Interleukin-10, Regulatory $T$ cells, Transforming Growth Factor- $\beta$

\footnotetext{
This is an Open Access article that uses a funding model which does not charge readers or their institutions for access and distributed under the terms of the Creative Commons Attribution License (http://creativecommons.org/licenses/by/4.0) and the Budapest Open Access Initiative (http://www.budapestopenaccessinitiative.org/read), which permit unrestricted use, distribution, and reproduction in any medium, provided the original work is properly credited.
}

Tropical Journal of Pharmaceutical Research is indexed by Science Citation Index (SciSearch), Scopus, International Pharmaceutical Abstract, Chemical Abstracts, Embase, Index Copernicus, EBSCO, African Index Medicus, JournalSeek, Journal Citation Reports/Science Edition, Directory of Open Access Journals (DOAJ), African Journal Online, Bioline International, Open-J-Gate and Pharmacy Abstracts

\section{INTRODUCTION}

Atherosclerosis is one of the metabolic disease characterized by blocked arteries [1]. In 2030, the prevalence of atherosclerosis disease is expected to increase to 23.3 million people. Atherosclerosis has a mortality rate of almost 50 $\%$ worldwide and is one of the largest cause of death in the developed country such as Indonesia [2]. It involves several cell interactions such as endothelial cells, machrophages, smooth muscle cells and lymphocytes. The accumulation of LDL (low density lipoprotein) is the main factor that causes atherosclerosis [3]. 
The accumulation of LDL, especially oxidatively modified LDL (Ox-LDL) in artery walls, triggers innate immune responses through the recruitment and activation of macrophages. This process then triggers the adaptive immune response through the activation of proinflammatory $T$ cells (Th1 subset) [4,5]. The accumulation of inflammatory cells in arteries causes the release of chemokines, interleukin, and protease such as interferon gamma (IFN- $\gamma$ ), tumor necrosis factor alpha (TNF- $\alpha$ ) and ligand CD40 membranes. The release of these molecules lead to increased immune response and atherosclerotic lesion progression [5]. For this reason, the role of regulatory $T$ cells is important for modulating the pro-inflammatory process into a pro anti-inflammatory process [3].

A medicinal plant that has often been used as an alternative treatment for reducing the risk of cloronary heart disease is garlic (Allium sativum L.) [6]. The cardiovascular properties of garlic are attributed to organosulfur compounds. Garlic contains 33 sulfur compounds (aliin, allicin, ajoene, allypropyl disulfide, and others), several enzymes (allinase, peroxidase and others), amino acids and minerals. Allicin is only produced when the garlic bulb is crushed or cut, activating the allinase enzyme, which metabolizes alliin to allicin [7]. Allicin has an antiinflammatory effect [8]. Allicin reduces the immune response due to oxLDL in atherosclerosis plaque formation. Free radicals can be suppressed in the presence of antioxidants. Administration of allicin has been reported to enhance the expression of SOD (superoxide dismutase) enzyme [9].

The single bulb garlic variety is usually used as traditional medicinal plant in Indonesia. This study aimed to analyze the effect of single bulb/clove garlic oil extract (SGO) on the activation of regulatory $T$ cells and antiinflammatory cytokines IL-10 and TGF- $\beta$ in mice fed a high-fat diet. Regulatory $T$ cells and antiinflammatory cytokines can be used as indicators to examine immune response related to atherosclerosis disease, in mice fed a high-fat diet.

\section{EXPERIMENTAL}

\section{Plant material}

Fresh bulbs of Allium sativum were collected and identified at UPT Materia Medica Batu, Malang, Indonesia on August 2017. A voucher specimen (no. T0-T0975) was prepared and deposited in the herbarium of the UPT Materia Medica Batu, Malang, Indonesia.

\section{Allium sativum extract preparation}

Preparation of single bulb garlic extract used a Soxhlet method with $\mathrm{N}$-hexane as the solvent about $0.9 \mathrm{~kg}$ of single bulb garlic powder (dried simplisia) was dissolved in $4.5 \mathrm{~L}$ of hexane. The final mass of the garlic oil extract was $6 \mathrm{mg}$. The extraction was done at UPT. Materia Medica Batu, Malang, Indonesia.

\section{Animal studies}

Twenty-four normal Balb/c male mice aged 12 weeks old ( $38 \pm 5 \mathrm{~g}$ ) were obtained from Gadjah Mada University, Yogyakarta, Indonesia. The mice were maintained in a pathogen-free facility. The experimental protocol was approved by ethical clearance from the Research Ethics Committee, Medicinal Faculty, Brawijaya University (no. 880-KEP-UB). All animal experiments were performed according to the Principles of Laboratory Animal Care $(\mathrm{NIH}$ publication no. 85-23) [10].

Twenty-four Balb/c male mice were randomly divided into six groups (four animals in each): $\mathrm{N}$-control group (normal diet); HFD—high-fat diet group; Simvas-HFD group receiving the Simvastatin $2.6 \mathrm{mg} / \mathrm{kg}$ BW; A1-HFD group receiving $12.5 \mathrm{mg} / \mathrm{kg}$ BW of SGO; A2-HFD group receiving $25.0 \mathrm{mg} / \mathrm{kg}$ BW of SGO; A3HFD group receiving $50.0 \mathrm{mg} / \mathrm{kg}$ BW of SGO.

\section{Atherosclerosis mice model and SGO extract treatment}

All mice were fed with standard diet for 1 week for acclimatization before study. For the HFD group, the mice were orally received HFD feed once a day for 45 days. HFD feed consisted of a $\mathrm{Hi}$-Grow Medicated 551 feed (30\%), duck yolk (10\%), coconut oil (30\%), wheat flour (5\%), corn $(24.9 \%)$, and cholic acid (0.1\%). The control group was fed the standard diet for 45 days. The various doses of single bulb garlic oil extract (SGO) were administered orally for four weeks.

\section{Lymphocyte isolation}

The mice were sacrificed and sectioned on week 12; spleens were then isolated and separated by gentle pipetting. The spleen suspension in propylene was added to Phosphate-buffered saline (PBS) up to $10 \mathrm{~mL}$ and then centrifuged at $2500 \mathrm{rpm}, 4^{\circ} \mathrm{C}$ for $5 \mathrm{~min}$. The supernatant was removed and the pellet was resuspended in $1 \mathrm{~mL}$ of sterile PBS to produce the lymphocyte suspension used for further analysis. 


\section{Lymphocyte count}

Lymphocyte count was calculated using a haemocytometer. A total of $10 \mu \mathrm{L}$ of the lymphocyte suspension and $90 \mu \mathrm{L}$ of Evans Blue were combined and homogenized in a microtube. The number of live lymphocytes was calculated using the formula:

$\Sigma$ Lymphocyte $=\Sigma$ lymphocyte count $\mathrm{x} 4 \mathrm{x}$ dilution factor $\times 10^{4} \mathrm{cell} / \mathrm{mL}$

\section{Antibody staining and flowcytometry analysis}

The lymphocyte suspension was co-incubated with FITC-conjugated rat anti-mouse CD4 and phycoerythrin (PE) anti-mouse CD-25 monoclonal antibodies for $15 \mathrm{~min}$. Antibodies used for intracellular staining were PE/Cy5 antimouse Foxp3, PE/Cy5 anti-mouse TNF- $\alpha$ and $\mathrm{PE} / \mathrm{Cy} 5$ anti-mouse IL-10. Antibodies were purchased from BioLegend, Inc (San Diego, CA). Next, $50 \mu \mathrm{L}$ cytofix-cytosperm was added to the pellet and incubated for $20 \mathrm{~min}$ at $4{ }^{\circ} \mathrm{C}$. Then, $500 \mu \mathrm{L}$ washperm was added and centrifuged at $2500 \mathrm{rpm}$ at $4{ }^{\circ} \mathrm{C}$, for $5 \mathrm{~min}$. The pellet was resuspended using $50 \mu \mathrm{L}$ of antibodies in sterile PBS. Next, the pellet was re-suspended in 500 $\mu \mathrm{L}$ PBS and assessed via a BD FACS Calibur ${ }^{\mathrm{TM}}$ flow cytometer (BD Biosciences, San Jose, CA, USA). The data were then processed using the BD Cell Quest Pro ${ }^{\mathrm{TM}}$ software.

\section{Statistical analysis}

Data are presented as mean \pm standard deviation (SD) and were analyzed using SPSS 16.0 for Windows. A one-way ANOVA was used to assess the statistical difference between the treatments. $P<0.05$ was defined as being statistically significant. Significant treatment effects was further analyzed for betweentreatment differences with the Tukey HSD Test.

\section{RESULTS}

\section{Effect of single bulb garlic oil (SGO) extract on level of regulatory $T$ cells $\left(\mathrm{CD}^{+} \mathrm{CD}^{+} 5^{+} \mathrm{Foxp}^{+}\right)$}

The effect of single bulb garlic oil (SGO) extract in mice fed a HFD could be seen clearly in the relative number of $\mathrm{CD} 4^{+} \mathrm{CD} 25^{+} \mathrm{Foxp}^{+} \mathrm{T}$ cells (Figure 1). A high-fat diet suppressed the activation of regulatory $T$ cells in mice. The relative number of $\mathrm{CD}^{+} \mathrm{CD} 25^{+} \mathrm{Foxp}^{+}$in the normal group was significantly decreased $(p<$ 0.05 ) after a HFD treatment for 45 days (19.62 vs $7.59 \%)$.
As seen in Figure 1, single bulb garlic oil (SGO) extract was able to promote the activation of regulatory $T$ cells in mice fed a high-fat diet. The relative number of $\mathrm{CD} 4^{+} \mathrm{CD} 25^{+} \mathrm{Foxp}^{+}$was increased significantly $(p<0.05)$ after administering SGO at a dose of $50.0 \mathrm{mg} / \mathrm{kg} \mathrm{BW}$ (A3) $(34.90 \%)$ compared to other doses. In A2 treatment, the relative number of $\mathrm{CD}^{+}{ }^{+} \mathrm{CD} 25^{+} \mathrm{Foxp}^{+}$also increased by $21.1 \%$ but not as high as in A3 treatment. The dose of 12.5 $\mathrm{mg} / \mathrm{kg}$ SGO did not restore the relative number of regulatory $T$ cells to the normal level $(17.28 \%)$.

Administration of simvastatin to HFD mice also increased the activation of Treg cells by $21.56 \%$, but not as high as A3 treatment $(p<0.05)$. SGO at $50.0 \mathrm{mg} / \mathrm{kg}$ was also effective in enhancing regulatory T cells that express Foxp3 in mice fed a HFD. Regulatory T cells that express Foxp3 have anti-inflammatory effect and secrete antiinflammatory cytokines IL-10 and TGF- $\beta$.

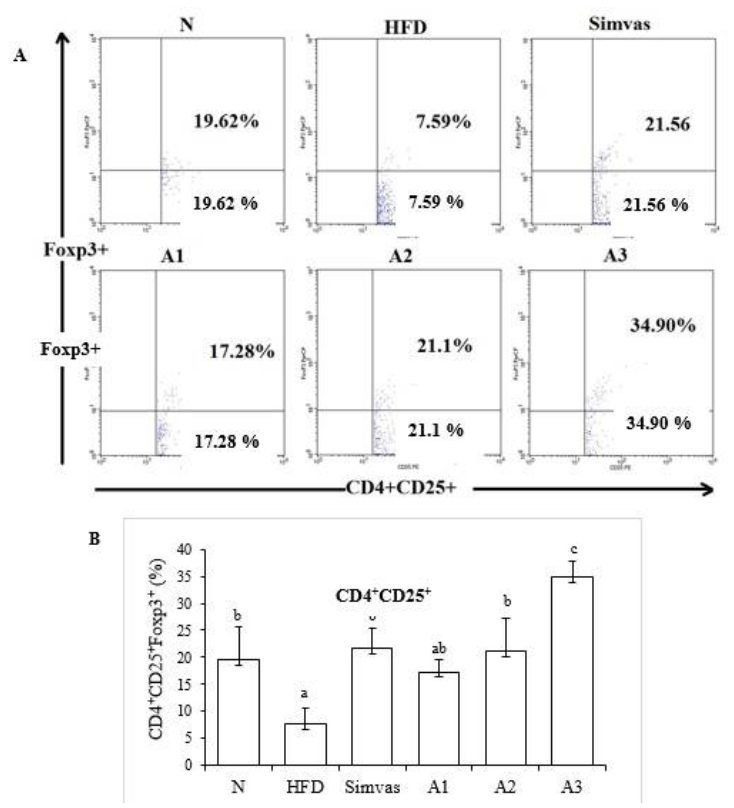

Figure 1: Effect of single bulb garlic ( $A$. sativum) oil (SGO) extract on the activation of regulatory $T$ cells in mice fed a high-fat diet (HFD). A) The relative number of Treg cells $\left(\mathrm{CD} 4^{+} \mathrm{CD} 25^{+} \mathrm{Foxp} 3^{+}\right)$in mice fed a HFD after 45 days of SGO treatment. B) The percentage of $\mathrm{CD}^{+} \mathrm{CD}^{2} 5^{+} \mathrm{Foxp}^{+}$after administration of SGO extract in mice fed a HFD. Data are mean $\pm S D(n=4)$. Note: $\mathbf{N}$ : normal mice (normal diet); HFD: high-fat diet mice; Simvas: high-fat diet mice receiving simvastatin dose of $2.6 \mathrm{mg} / \mathrm{kg}$ BW; A1: HFD mice receiving SGO 12.5 $\mathrm{mg} / \mathrm{kg}$ BW; A2: HFD mice receiving SGO $25.0 \mathrm{mg} / \mathrm{kg}$ BW; A3: HFD mice receiving SGO $50.0 \mathrm{mg} / \mathrm{kg} \mathrm{BW}$

\section{Effect of single bulb garlic oil (SGO) extract on IL-10 production (CD4 ${ }^{+}$CD25 ${ }^{+} \mathrm{IL}-10^{+}$)}

IL-10 is a suppressive cytokine known as being effective in reducing inflammation in atherosclerosis disease. We observed that a 
high-fat diet suppressed the production of IL-10. The relative number of $\mathrm{CD} 4^{+} \mathrm{CD} 25^{+} \mathrm{IL}-10^{+}$was significantly decreased $(p<0.05)$ in mice fed a HFD compared to normal mice (11.90 vs 23.39 $\%$ ) (Figure 2). Flowcytometry analysis showed that administration of SGO significantly increased the production of IL-10 by Treg cells in all treatment doses of SGO (A1: $26.03 \%$; A2: 38.48 $\%$; A3: $34.87 \%$ ). This results suggests that $A 2$ group (SGO dose of $25.0 \mathrm{mg} / \mathrm{kg} \mathrm{BW}$ ) had a higher level of IL-10 compared to other doses. As seen in Figure $2 \mathrm{~B}, \mathrm{~A} 2$ group was not significantly different in the relative level of IL-10 as compared to the simvastatin group (Simvas: $46.44 \%)$.

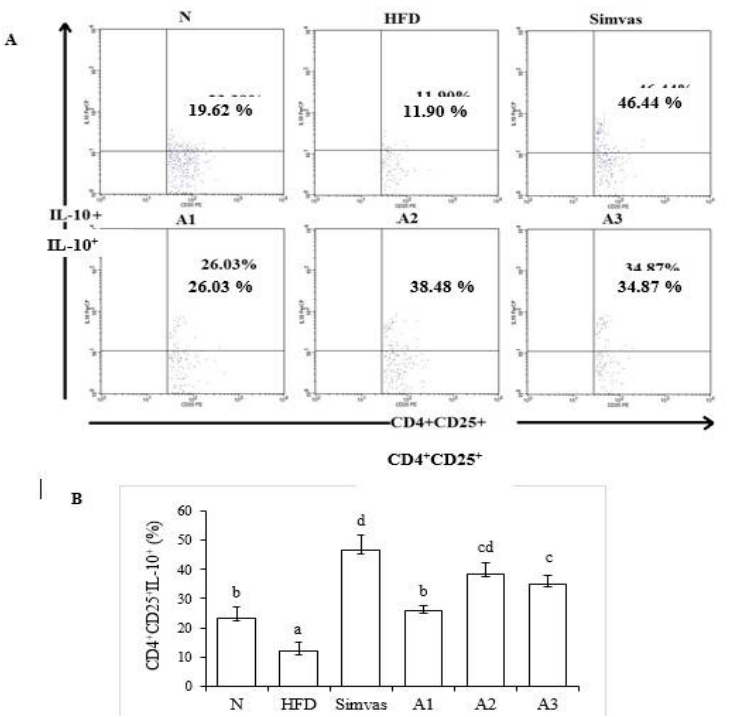

Figure 2: The effects of single bulb garlic ( $A$. sativum) oil (SGO) extract on IL-10 production in mice fed a high-fat diet (HFD). A) The relative level of IL-10 $\left(\mathrm{CD} 4^{+} \mathrm{CD} 25^{+} \mathrm{IL}-10^{+}\right)$in mice fed a HFD after 45 days of SGO extract treatment. B) The percentage of $\mathrm{CD} 4^{+} \mathrm{CD} 25^{+} \mathrm{IL}-10^{+}$after administration of SGO extract in mice fed a HFD. Data are mean $\pm S D(n=4)$. Note: $\mathbf{N}$ : normal mice (normal diet); HFD: high-fat diet mice; Simvas: high-fat diet mice receiving simvastatin at dose of $2.6 \mathrm{mg} / \mathrm{kg}$; A1: HFD mice receiving SGO 12.5 $\mathrm{mg} / \mathrm{kg}$; A2: HFD mice receiving SGO $25.0 \mathrm{mg} / \mathrm{kg}$; A3: HFD mice receiving SGO $50.0 \mathrm{mg} / \mathrm{kg}$

\section{Effect of single bulb garlic oil (SGO) extract on TGF- $\beta$ production (CD4 ${ }^{+}$CD25 ${ }^{+}$TGF- $\beta^{+}$)}

The administration of SGO to mice fed HFD showed significant increase in the production of TGF- $\beta$. TGF- $\beta$ is important in controlling inflammation. Flow cytometry analysis showed that the relative level of $\mathrm{CD}^{+} \mathrm{CD} 25^{+} \mathrm{TGF}-\beta^{+}$ decreased significantly $(p<0.05)$ in mice fed a high-fat diet and treatment with $50.0 \mathrm{mg} / \mathrm{kgBW}$ dose of SGO (A3: $20.10 \%$ vs HFD: $15.25 \%$ ) reversed it (Figure 3 ). The relative level of TGF- $\beta$ at dose $50.0 \mathrm{mg} / \mathrm{kg}$ of SGO was increased by $20.10 \%$ compared to normal mice $(19.99 \%)$.
The A3 group ( $50.0 \mathrm{mg} / \mathrm{kg}$ of SGO) appeared to have been administered the optimal dose, which increased the anti-inflammatory TGF- $\beta$ compared to other doses of SGO and simvastatin group in atherosclerosis mice model. Increasing levels of TGF- $\beta$ is crucial for the progression of atherosclerosis to result in inflammation, fibrosis, chemotaxis, proliferation, and apoptosis.

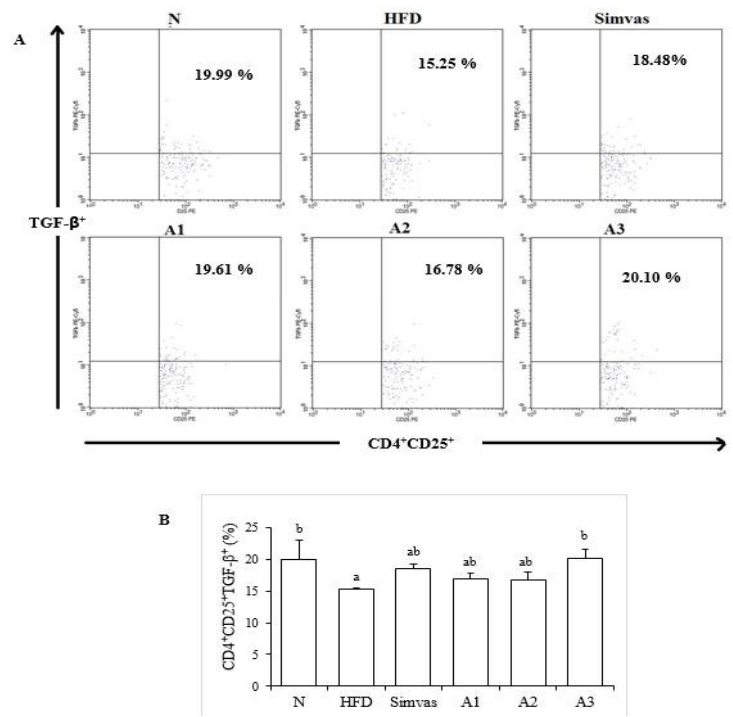

Figure 3: The effects of single bulb garlic ( $A$. sativum) oil (SGO) extract on TGF- $\beta$ production in mice fed a high-fat diet (HFD). A) The relative level of TGF- $\beta$ $\left(\mathrm{CD} 4^{+} \mathrm{CD} 25^{+} \mathrm{TGF}-\beta^{+}\right.$) in mice fed a HFD after 45 days of SGO treatment. B) The percentage of CD4 ${ }^{+}$CD2 $5^{+}$TGF- $\beta{ }^{+}$after administration of SGO extract in mice fed a HFD. Data are mean \pm SD $(n=$ 4). Note: N: normal mice (normal diet); HFD: high-fat diet mice; Simvas: high-fat diet mice recieving simvastatin dose of $2.6 \mathrm{mg} / \mathrm{kg}$; A1: HFD mice receiving SGO $12.5 \mathrm{mg} / \mathrm{kg}$; A2: HFD mice receiving SGO 25.0 mg/kg; A3: HFD mice receiving SGO 50.0 $\mathrm{mg} / \mathrm{kg}$

\section{DISCUSSION}

Regulatory $\mathrm{T}$ cells $\left(\mathrm{CD} 4^{+} \mathrm{CD} 25^{+} \mathrm{FOXP} 3^{+}\right)$are the main factors involved in immune tolerance and induction [11]. Treg cells $\mathrm{CD}^{+} \mathrm{CD} 25^{+} \mathrm{FOXP3}^{+}$ from the thymus are found in atherosclerotic lesions [12]. Treg cells have a suppressive effect and level of Foxp3 expression determines their suppressive role [13]. Treg cells-expressing Foxp3 secreting the anti-inflammatory cytokines IL-10 and TGF- $\beta$ [14].

The function of Treg cells is closely related with the effect of suppressive cytokines such as TGF$\beta$ and IL10. Some research has reported that Treg cells secrete several cytokines such as TGF- $\beta$ and IL10 that inhibit the activation of certain cells [15]. IL-10 is an anti-inflammatory cytokine that is effective in atherosclerosis

Trop J Pharm Res, November 2018; 17(11): 2160 
protection; IL-10 exerts its atheroprotective effect on plaque progression, as well as the different stages of atherosclerosis by influencing the local inflammatory process within the atherosclerotic lesion [16]. Decreasing levels of IL-10 lead to MMP accumulation which may promote instability of atherosclerotic plaque [17-19].

Therapy with suppressive cytokines is important for decreasing the progression of inflammatory disease, especially atherosclerosis. The present study found that IL-10 cytokines by Treg cells are crucial factor for reducing the progression of atherosclerosis in mice fed a high-fat diet. The increasing levels of IL-10 due to administration of SGO is one therapy that may be applied to individuals with atherosclerosis disease. Many studies have revealed that TGF- $\beta$ may inhibit the progression of atherosclerosis disease. One of the possible pathways that it may affect is the inhibition of proliferation, migration and apoptosis of smooth muscle cells and endothelial cells and also potentially inhibits the immune system. Activated Treg cells have a large effect on IL-10 and TGF- $\beta$ secretion [3].

This study showed that the increase of Treg cells activation followed by the production of the antiinflammatory cytokines IL-10 and TGF- $\beta$ in mice fed a HFD and administered SGO indicated that there are active compounds in single bulb garlic that may activate Treg cells. Furthermore, the level of regulatory $T$ cells activated by SGO was higher than that of simvastatin group. Simvastatin is a drug used commonly to treat hypercholesterolemia and coronary heart disease. This study used simvastatin as a positive control; simvastatin is known to inhibit 3hydroxy-3-methyl-glutaryl-coenzyme A (HMGCoA) reductase, which catalyzes cholesterol formation. Suppression of this enzyme (HMGCoA reductase) have an effect on the ROS reduction and increasing of oxidised LDL resistant [20].

Single clove garlic (Allium sativum L.) has been used for traditional medicine, likely because of efficacy of organosulfur compounds present in it such as diallyl disulfide, S-allylcystein and diallyl trisulfide, or allicin, which is enzymatically produced upon injury to the bulb $[21,22]$. Recent studies have demonstrated a pharmacological effect of $A$. sativum, especially the active compound allicin. Some studies suggest that allicin and sulfur compounds in single clove garlic posses' antifungal, antibacterial, antiparasitic, antiviral, anticancer and cardiovascular protective effects. Some cardiovascular protective effects may be anti-hypertensive [27], antiatherosclerotic and antithrombotic [23].
Research by Wang and $\mathrm{Ng}$ [24] reported that garlic has protective effect for atherosclerosis disease. Abramovitz et al [25] have shown that allicin compounds in garlic clove reduce the serum cholesterol and LDL levels. Allicin significantly suppressed oxidized LDL and atherosclerosis progression [22, 23]. The active compound of garlic that has an anti-atherogenic role are mostly found in the oil fraction [23]. Currently, there is no research on the effect of garlic in the activation of immune cells. SGO reduce the migration of neutrophils by endothelial cells and have an effect on $T$ lymphocyte function in extravascular inflammatory sites [23]. This study suggests that garlic oil extract may be a suitable alternative herbal treatment for the prevention of atherosclerosis.

\section{CONCLUSION}

These results suggest that SGO inhibits inflammatory processes in mice fed a HFD, by enhancing regulatory $T$ cells and the antiinflammatory cytokine IL-10 and TGF- $\beta$. Thus, SGO can be developed as a food supplement and/or therapeutic agent to ameliorate inflammation disorders caused by HFD.

\section{DECLARATIONS}

\section{Acknowledgement}

We would like thank Bambang Pristiwanto and Yuyun Ika Christina to help us assits the research. The research supported by UPT Balai Materia Medika-Batu and funding by Ministry of Research, Technology and Higher Education of Republic Indonesia (grant no. 3.4.8/UN.32.14. LT/2017).

\section{Conflict of interest}

No conflict of interest is associated with this study.

\section{Contribution of authors}

We declare that this work was done by Sri Rahayu Lestari and Muhaimin Rifa'i and all liabilities pertaining to claims relating to the contents of this article will be borne by the authors. Sri Rahayu Lestari performed the study design and drafting the manuscript and Muhaimin Rifa'i performed the final approval of the manuscript. 


\section{REFERENCES}

1. Rastini EK, Widodo MA, Rohman MS. Pengaruh Pemberian Ekstrak Buah Mengkudu (Morinda citrifolia L.) terhadap Ekspresi NF-K $\beta$ dan Ekspresi Protein (TNFa, ICAM-1) pada Kultur Sel Endotel (HUVECs) Dipapar OxLDL. J Exp Life Sci 2010; 1(1): 48-55.

2. World Health Organization (WHO). Non-Communicable Disease (NCD) Country Profiles 2014, 2014 [cited 2014 Mar 8]. Available from: http://www.who.int/nmh/publi cations/ncd-profiles-2014/en/.

3. Christiakov DA, Sobenin IA, Orekhov AN. Regulatory $T$ cells in atherosclerosis and strategies to induce the endogenous atheroprotective immune response. Immunol Lett 2013; 151(1-2): 10-22. doi: 10.1016/j.imlet.2013.01.014.

4. Hansson GK, Libby $P$. The immune response in atherosclerosis: a double edged sword. Nat Rev Immunol 2006; 6(7): 508-19. DOI: 10.1038/nri1882.

5. Entin-Meer M, Afek A, George J. Regulatory T-Cells, FoxP3 and Atherosclerosis. Adv Exp Med Biol 2009; 665: 106-114.

6. Handayani L. Potensi bawang putih sebagai obat tradisional/herbal dalam pelayanan kesehatan. Majalah Kedokteran Indonesia 2006; 56(2): 64-70.

7. Hernawan UE, Setyawan AD. Review: Senyawa Organosulfur Bawang Putih (Allium sativum L.) dan Aktivitas Biologinya. Biofarmasi 2003;1(2): 65-76.

8. Lee DY, Li H, Lim HJ, Lee HJ, Jeon R, Ryu JH. Antiinflammatory Activity of Sulfur-Containing Compound from Garlic. J Med Food 2012; 15(11): 992-999. doi: 10.1089/jmf.2012.2275.

9. Arreola R, Fabian SQ, Lopez-Roa RI, Gutierrez EOF, Grajeda JPR, Quintanar LC, Sahagun DO. Immunomodulation and Anti-Inflammatory Effects of Garlic Compound. J Immunol Res 2015; 2015: 1-13. doi: http://dx.doi.org/10.1155/2015/401630.

10. Derrell C. "Guide for the care and use of laboratory animals. Institute of laboratory animal resources. National Academy Press, Washington DC, USA; 1996.

11. Lee $Y$-H, Rifa'l M. CD4+CD25+FOXP3+ regulatory $T$ cells in allogeneic hematopoietic cell transplantation. $J$ Trop Life Sci 2011; 1: 1-8.

12. Rohm I, Atiskova $Y$, Drobnik $S$, Fritzenwanger $M$, Kretzschmar D, Pistulli R, Zanow J, Krönert T, Mall G, Figulla HR, Yilmaz A. Decreased regulatory $T$ cel is in vulnerable atherosclerotic lesions: imbalance between pro and anti-inflammatory cells in atherosclerosis. Mediators Inflamm 2015; 2015(2015): 1-13. Doi: http://dx.doi.org/10.1155/2015/364710.

13. Chauhan SK, Saban DR, Lee HK, Dana R. Levels of Foxp3 in regulatory $T$ cells reflect their functional status in transplantation. J Immunol 2009; 182(1): 148-153.
14. Kyaw T, Ban-Hock T, Bobik A. Foxp3+CD4+ Regulatory T-Cell Subtypes and Atherosclerosis. Circu Res 2016; 119(11):1151-1153. doi: 10.1161/CIRCRESAHA. 116.309999.

15. Rifa'l M, Widodo $N$. Significance of propolis administration for homeostasis of $C D 4+C D 25+$ immunoregulatory $T$ cells controlling hyperglycemia. Springer Plus 2014; 3(526): 1-8.

16. Libby P, Ridker PM, Hansson GK. Progress and challenges in translating the biology of atherosclerosis. Nature 2011; 473(7347): 317-325. doi: 10.1038/nature10146.

17. Mallat Z, Besnard S, Duriez M, Deleuze V, Emmanuel $F$, Bureau MF, Soubrier $F$, Esposito B, Duez $H$, Fievet $C$, et al. Protective role of interleukin-10 in atherosclerosis. Circ Res 1999; 85(8): e17-24.

18. Holven KB, Halvorsen B, Bjerkeli V, Damas JK, Retterstol K, Morkrid L, Ose L, Aukrust P, Nenseter MS. Impaired inhibitory effect of interleukin-10 on the balance between matrix metalloproteinase-9 and its inhibitor in mononuclear cells from hyperhomocysteinemic subjects. Stroke 2006; 37: 1731-1736. DOI: 10.1161/01.STR.0000226465.84561.cb.

19. Amento EP, Ehsani N, Palmer H, Libby P. Cytokines and growth factors positively and negatively regulate interstitial collagen gene expression in human vascular smooth muscle cells. Arterioscler Thromb 1991; 11(5): 1223-1230.

20. Rosenson RS. Statins in atherosclerosis: lipid-lowering agents with antioxidant capabilities. Atherosclerosis 2004; 173(1):1-12. Doi: https://doi.org/10.1016/S00219150(03)00239-9.

21. Mikaili P, Maadirad S, Moloudizargari M, Aghajanshakeri $S$, Sarahroodi S. Therapeutic Uses and Pharmacological Properties of Garlic, Shallot, and Their Biologically Active Compounds. Iran J Basic Med Sci 2013; 16(10): 1031-1048.

22. Stoll $A$, Seebeck E. Chemical investigations on alliin, the specific principle of garlic. Adv Enzymol Relat Subj Biochem 1951; 11:377-400.

23. Appel E, Vallon-Eberhard A, Rabinkov A, Brenner O, Shin I, Sasson K, Shadkchan Y, Osherov N, Jung S, Mirelman $D$. Therapy of murine pulmonary aspergillosis with antibody-alliinase conjugates and alliin. Antimicrob Agents Chemother 2010; 54(2):898-906. doi: 10.1128/AAC.01267-09.

24. Wang HX, Ng TB. Natural products with hypoglycemic, hypotensive, hypocholesterolemic, antiatherosclerotic and antithrombotic activities. Life Sci 1999; 65(25): 2663-2677.

25. Abramovitz $D$, Gavri $S$, Harats $D$, Levkovitz $H$, Mirelman $D$, Miron T, Eilat-Adar S, Rabinkov A, Wilchek M, et al. Allicin-induced decrease in formation of fatty streaks (atherosclerosis) in mice fed a cholesterol-rich diet. Coron Artery Dis 1999; 10(7): 515-519. 